\title{
The Role of Market Associations in the Development of Oja'oba Market in Ibadan
}

\author{
P.O. Oyewale, PhD \\ Department of History and International Studies \\ Faculty of Arts, Ekiti State University, Ado-Ekiti, Ekiti State, Nigeria
}

\begin{abstract}
Market Associations is an integral phenomenon on economic activities in Yorubaland. This study is an historical examination of the contribution of Market Associations to the growth and development of Oja'Oba market in Ibadan. It examines various associations in Oja'Oba market in Ibadan and their formations. The study revealed that the success of economic transactions in a market economy is determined by medium of exchange and availability of market associations which provide social interactions to individual involved in market transactions. The study derived its data from primary and secondary sources. The study concluded that market associations contributed greatly to the evolution of Oja'Oba market in Ibadan by providing links between traders, financial assistance to members and arbiters in conflict resolution.
\end{abstract}

Key Word: Market, Association, Ibadan, Conflict, Ibadan

\section{Introduction}

Association is the coming together of craftsmen, merchants and traders to form mutual aid and protection and for the furtherance of their professional interests. ${ }^{1}$ Market association is mainly a capacity-based contributory scheme designed to enhance the economic empowerment of its members. The association process could therefore be simply defined as a co-ordinated effort by which an organisation is official to have the responsibility for the monitoring of economic activities of its members to ensure that production relation is smooth, consistent and unhampered by discreet actions of members and non-members of the organisation. $^{2}$

This then implies that association symbolized the legitimate authority which regulated or guaranteed professional conduct or ideal commercial practices in our society. The association also engaged in a sort of contributory scheme which provided support and

\footnotetext{
${ }^{1}$ Trader Association www.britannica.com/topic/trade-association

${ }^{2}$ A.O.Y Raji and T.S. Abejide. The Guild System and its Roles in the Economy of Pre-Colonial Yorubaland.Arabian Journal of Business and Management Review, Vol.3, No.3; 2013, pg.2
} 
empowerment for its members. ${ }^{3}$ It is equally evident that for every profession, the scheme provided or established ethical standards for all its members. The operational limits of the associations in Yorubaland actually outstretched economic or commercial lines. The nature of economic organization in several Yoruba kingdoms gave the privilege of production and exchange to individuals and groups in the society. Those who engaged in the task of entrepreneurship and who had the resources or means of production actually employed the services of the labour provided by the family as well as the slaves to achieve for their immediate and long-term benefits the goal of production and exchange.

Among the Yoruba during the pre-colonial period, each town or state organised its own association. ${ }^{4}$ Within every settlement or town, the association process had three main categories which were:

i. The association of general traders (Egbe Alajapa) that traded largely in inanimate objects such as medicinal herbs, fruits and other food items. ${ }^{5}$

ii. The association of traders (Egbe Alaroobo) that trade in different types of animate objects such as fowls, goats, etc. It is observed that members of both associations often engaged in medium and long distance trading, as they moved round other towns and villages to collect their articles for sale in other larger towns or in their own town markets. ${ }^{6}$

iii. The specialized associations of traders, tradesmen or professionals. Such associations were named after the particular items they traded in or after their profession. These included, for example, Egbe alaso (association of cloth dealers), Egbe olose (association of soap makers), Egbe alaro (association of dyers), Egbe alata (association of pepper sellers), Egbe eleni (association of mat makers), Egbe alagbede (association of smelters), etc. All persons involved in the production and/or sale of the same objects or engaged in the same profession would be expected to organise themselves into or belong to an association whether on local or regional basis. Since trading was a major task of women,

\footnotetext{
${ }^{3}$ Ibid

${ }^{4}$ I.A. Akinjogbin, "The Economic Foundations of the Oyo Empire: in Akinjogbin and Osoba (Eds.), Topics on Nigerian Economic and Social History. Ife: Unife Press Ltd, 1981

${ }^{5}$ T. Falola, Political Economy of a Pre-Colonial African State: Ibadan, 1930-1900. Ile-Ife: Unife Press Ltd, 1983, p.169

${ }^{6}$ I.A. Akinjogbin, "The Economic Foundations of the Oyo Empire: in Akinjogbin and Osoba (Eds.), Topics on Nigerian Economic and Social History. Ife: Unife Press Ltd, 1981, 71
} 
most of the associations were actually dominated by the women folk especially in commercial activities within the coastal belt, ${ }^{7}$ and also in the Yoruba hinterland. ${ }^{8}$

\section{Origin of Ibadan as a Yoruba town}

Ibadan came into existence in 1829 when Lagelu, the Jagun (Commander-in-Chief) of Ife and Yorubas in general, left Ife with a handful of people from Ife, Oyo and Ijebu to found a new city, Eba Odan, which literally means 'between the forest and plains'. According to Sir Isaac Babalola Akinyede, the late Olubadan (King) of Ibadan in his authoritative book ${ }^{9}$ on the history of Ibadan, Iwe Ibadan, printed in 1911, the first city was destroyed due to an incident at an Egungun (masquerade) festival when an Egungun was accidentally disrobed and derisively mocked by women and children in an open market place full of people. In Yorubaland, it was an abomination for women to look an Egungun in the eye because the Egunguns were considered to be the dead forefathers who returned to the earth each year to bless their progeny. When the news reach Sango, the then Alaafin of Oyo, he commanded that Eba Odan be destroyed for committing such abominable act. Lagelu was old at the time Eba Odan was being destroyed; he could not stop the destruction of his city but he and some of his people survived that attack and fled to a nearby hill for sanctuary. After a while, Lagelu and his people came down from the hill and founded another city called Eba'dan. ${ }^{10}$

The new city instantly grew prosperous and became a commercial nerve centre. Shortly afterwards, Lagelu died, leaving behind a politically savvy people and a very stable community. The newly enthroned Olubadan made a friendly gesture to the Olowu of Owu by allowing Olowu to marry his only daughter; Nkan coming from a war campaign one day, the raging Odo Oba (River Oba) would not allow Olowu and his army to cross until a human sacrifice was performed to appease the angry river. The chosen sacrifice was Nkan. The Olubadan was infuriated at hearing of Nkan's death; he sent an emissary to inform the Alaafin of Oyo. Yoruba kings and rulers such as Alake of Egba, Agura of Gbagura, Ooni of Ife, Awujale of Ijebu and others formed a formidable condition with Eba'dan against the powerful Olowu of Owu. After the defeat of Owu, many of the warriors that participated in the

\footnotetext{
${ }^{7}$ J.H. Kopytoff, A Preface to Modern Nigeria: The Sierra Leonians in Yoruba, 1830-1890, Madison, 1965.

${ }^{8}$ Vagale, L.R. (1972). Anatomy of Traditional Markets in Nigeria. Ibadan University: Institute of African Studies.

${ }^{9}$ Sir I.B. Akinyele, The History of Ibadan (Iwe Ibadan), Printed in 1911.

${ }^{10}$ Ibid
} 
condition refused to go back to their towns and cities except the Ijebu warriors. They began attacking the neighbouring towns and hamlets, and also marauded across Eba'dan thereby making the indigenes fearful of them. Finally, they took over the political landscape of Eba'dan and changed its name to Ibadan, as we have come to know it.

\section{The Creation of Oja'ba}

Oja'ba coined from a great warrior known as Ibasorun Oluyole who died in 1849. The market was name after him. ${ }^{11}$ The Oluyole compound is situated in the center of the market. According to the present family head Alhaji Nureni Adebayo Akanbi, he said there is no particular date attached to the creation of Oja'ba. There are people from other tribes that trade in Oja'ba like the Hausa people who were the first settlers then the Igbo people and the other tribes joined them in trade. The market started and still operates as a deadly market.

Oja'ba is in the center of Ibadan, located in the South East local government area which was created on $27^{\text {th }}$ August, 1991 followed by the nationwide broadcast of May $3^{\text {rd }}$ 1989 when the President and Commander in Chief of the Armed Forces, General Ibrahim Babangida announced the creation of additional one hundred and fifty-nine (159) local governments areas all over the country.

Economic activities in Ibadan South East Local Government include the activities of about 70 percent who are engaged in trading. ${ }^{12}$ This is followed by craftsmanship/service industry which takes 20 percent of the total, others activities are public service and manufacturing industry which account for 8 percent and 2 percent respectively.

Oja'ba is situated opposite the Olubadan palace which stands beside the Ibadan central city hall, at Mapo Hill. This palace spot was the former spot of Okebadan shrine before it was relocated to Ibadan South West local government. Commerce and trade account for the largest proportion of the economic activities. Other activities include farming, industry/manufacturing, animal husbandry/poultry and craftsmanship.

\section{Growth and Development of Oja'ba}

\footnotetext{
${ }^{11}$ Interview with Alhaji Nureni Adebayo Akanbi, family head of Oluyole compound, Oja'ba

${ }^{12}$ Gbenga Abiola, Great Strides at Mapo Hill, the Seat of Ibadan South East Local Government, 2005.
} 
As humans are considered as consumers, therefore, their needs and wants cannot be satisfied. This, however, explains the intensity of demand on goods in order to maintain and possibly improve their standard of living. Moreover, food has been the basic and most important necessity to keep the body functioning well. Generally, markets of food stuff attract a large number of people making up of the traders and buyers.

Furthermore, as long as the news of the existence of a foodstuff market where across the urban centres, especially where quick, cheap and affordable commodities can be purchased, there will be also be numerous consumers to visit such a food distributing centre. Oja'ba is known basically, for the sale of food items. The traders major in the sale of kola nut, pepper, meat and foodstuff like rice, beans, garri, yam flour, yam tubers, etc. They also deal with traditional cloths like ofi/aso oke and the likes. This food stuff market is concerned with the daily needs of its consumers both urban and rural dwellers because it is situated between them.

The location of the market favoured traders coming from Lagos, Abeokuta and other neighbouring towns to buy goods from Oja'ba especially fruits, aso-oke and foodstuff. Also, the accessible road network greatly blossomed the market activities such that farmers from other areas in Ibadan, Omi-Adio, Abeokuta etc. came to sell their foodstuffs in the market to prospective consumers travelling in and around the town. Furthermore, the activities of artisans such as shoe makers, drivers, mechanics, weavers and blacksmith specializing in different crafts also facilitated the growth and expansion of market activities within the market. $^{13}$

Population expansion and diversification of human activities is another important factor which facilitated the growth and development of the market and diversification of human activities. In the early period, the town witnessed rise in its population. Throughout the early twentieth century, till the present period, the population continually expands. This relatively large population pursued a variety of economic activities in the town, principally, farming and trading, augmented by specialized crafts like blacksmithing, weaving, dye, agricultural production of yam, maize, cassava and other crops was largely on the subsistence level, while the production of cash crops like cocoa, palm oil, kolanut and timber expanded in

\footnotetext{
${ }^{13}$ Gbenga Abiola, Great Strides at Mapo Hill, the Seat of Ibadan South East Local Government, 2005.
} 
the 1970s and 80s. ${ }^{14}$ The increase in food production stimulated marketing activities which in turn facilitated the growth of Oja'ba market. Oba'ba market, being one of the major markets in Ibadan benefited from the general expansion of economic activities in Yorubaland. ${ }^{15}$

Prices of commodities, especially foodstuff are determines through haggling and bargaining. The difference between a price originally quoted for an article and its sale price may be much depending on how skillful the buyers are in the bargaining process. Pricing of commodities also depends on weight and measures and on the quantity and quality of the commodities. Qualities that are taken into account in fixing prices include dampness content, degree of foreign matter, insects, processing color, flavor, smell, etc. ${ }^{16}$

The market has attracted a large crowd of patronizers around the area because of the establishment of some institutions in the local government area. The growth and development of Oja'ba as described by some traders like Mrs. Oredun who sells foodstuffs, and has been in the market since 1985, said, that market sales were quite good, and that civilization has changed operation and everything that has to do with trade in Oja'ba. ${ }^{17}$ Mrs. Majobaje, who sells vegetable oil since 1974, claims that there was money and that things were good. ${ }^{18}$ But, those things are not the way it used to be, there are challenges/problem which will be discussed later.

Market associations also play an important role in the growth and development of Oja'ba market. The exact date of the establishment of market association is vague and one cannot say precisely when it started. ${ }^{19}$ However, it is generally believed in the early years of the twentieth century, production and marketing began to be organized through trade associations. It is important to note that these associations deem it fit to come together as there was an increase in the traders dealing in a particular kind of commodity to be able to know one another and to understand one another's problem in the course of their trade and also to educate their members in the same profession about new areas of available goods, for

${ }^{14}$ Oladiti, A.A. “Traditional Market in Modern Ibadan: A Case Study of Oja'ba 1970-1996”, B.A. Dissertation Department of History, University of Ibadan.

${ }^{15}$ Ibid

${ }^{16}$ Vagale, L.R. (1972). Anatomy of Traditional Markets in Nigeria. Ibadan University: Institute of African Studies.

${ }^{17}$ Oral interview with Mrs. T. Oredun, age 50, Foodstuff trader, Oja'ba Ibadan, $28^{\text {th }}$ August, 2020

${ }^{18}$ Oral interview with Mrs Mary Majobaje, age 62, Trader, Ibadan, $28^{\text {th }}$ August, 2020

${ }^{19}$ Ogunsanwo, A.T. "Traditional market in Modern Ibadan: A Case study of Oje market, 1960-1984”, B.A. Dissertation, Department of History, University of Ibadan, (1985), p.18 
the producers and the provision of short term credit facility for members with little or no interest. $^{20}$

It is also important to note that market associations also contributed money to clear public heaps of refuse, which accumulate around the centre of the market.

As earlier mentioned, effective transportation system makes marketing of foodstuffs easy. It is through effective transportation that foodstuffs get to Oja'ba market, because different road links to the market and are distributed to other markets in Ibadan. Transportation is important for smooth trading, and without it no commodity could get to Oja'ba market from places of production. In a nutshell, transportation networks in Oja'ba market are very effective toward the distribution of farm produce and other foodstuffs in the town. This has contributed in no small measure to the growth and development of market and marketing activities in the town.

There are basic strategies put in place by the local government to help boost the economic growth of the people in these areas, which has also helped the development of Oja'ba. These strategies range from agriculture, trade and industry, social sector, education, etc. for agriculture

a. Workshops/training on various aspects of agriculture to empower new entrants into farming: poultry, fish farming, etc.

b. Making available soft loan to new and existing farmers

c. Provision of agricultural equipment and facilities of farmers

i. Provision of more tractors, plough, etc.

ii. Training for farmers on modern methods of farming, processing and storage of farm produce.

iii. Construction of storage facilities for grains and other crops: maize, beans, yam, cassava

iv. Trade and Industry: the local government will employ the following to encourage the establishment and development of micro, small and medium enterprises in the local government area and build needed capacity in women and youths to make them productive

\footnotetext{
${ }^{20}$ Akintoye, S.A. (1977), Revolution and Power Politics in Yorubaland 1840-1893. Ibadan Expansion and the Rise of Ekitiparapo. London: Longman, 1977, p.15
} 


\section{Organization of Oja'ba in Ibadan}

The organization of any market is very important for the development and maintenance of activities. ${ }^{21}$ The organization of Oja'ba basically consists of structures and administration of the market.

The structures in Oja'ba were majorly built by traders themselves by the pattern laid down by the local government. Traders also bring their commodities to the roadside where prospective buyers could call to purchase their foodstuffs and other household necessities. However, the traders that extend their good to the available open spaces or roadside create problems when it comes to movement. The local government levies the occupier of the open spaces where retailed foodstuffs are on display.

There is a record of over hundred shops and there are shrines located in the market, for example Ogun shrine, Oke Ibadan shrine etc. ${ }^{22}$ All these shrines have their individual purpose in the market.

\section{Administration and Management}

Like most markets in Yorubaland, Oja'ba is another market where each of the commodities displayed has an association formed within the market majorly administered by women. This commodity association in Oja'ba has always been carried along on the organization and management of affairs in the market. These associations are registered with the local and state government. These associations aim at the development of the market, ensuring existence of mutual benefits through marketing procedures. The various commodity associations have governing executives and are usually bonded with a set of rules and regulations which include: the control of the entrance of people into trade in the market, punctuality in meetings, members of the associations must not fight or dupe one another; members must not sell commodities at exorbitant rates, etc.

The Ibadan South East Local Government made available vital infrastructures, apart from the construction of the market stalls in Oja'ba. For water supply public wells were dug, public taps and boreholes as well were made available for use by traders. Environmental

\footnotetext{
${ }^{21}$ Topics in Nigerian Socio-Economic History. I.A Akinjogbin and Segun O. Osoba

${ }^{22}$ Interview with Alhaji Nureni Adebayo Akanbi, family head of Oluyole Compound Oja'ba Ibadan, $25^{\text {th }}$ of April, 2020
} 
sanitation officers, health workers are always in the market to ensure strict compliance with sanity regulations. ${ }^{23}$ There is a police station situated beside the Olubadan palace for the market and environs for maintenance law and order in the market.

Beside the state government supervision of the revenue collection from the market which includes ground rent, car park fees and slaughter fees, hawkers permit, liquor license and advertisement fees. They also monitor the affair of trading activities in the market. The state governments got involved in monitoring the prices of commodities sold in the market, with the view of controlling inflation in urban economy.

The traditional commodity associations have been transformed into a partner-inprogress with both the local and state government. The heads of commodity associations in Oja'ba hold regular meeting with the local government officials but also make representations on any economic policy, to the state governor. However, allocation of stalls built by the Ibadan South East Local Government is anchored on the recognition of the commodity associations. The local government has always been maintaining good report with the executives of the associations for effective management of Oja'ba and other markets under its jurisdiction. ${ }^{24}$

The commodity associations carry out various activities in Oja'ba. They ensure thorough cleanliness of stalls and its environs. They ensure compliance with government trade policies and payment of commodity tax. In order for the traders to comply with accepted norms in the markets such as controlling the sale of commodity for a specific period and the opening hours to the overall executive of all the associations have empowered a time keeper to make public announcements as early as marketing operations are about to commence. ${ }^{25}$

Speaking here, of social activities, the commodity associations perform numerous functions within and outside the market. Each association has a specific period of celebration of at least once in a year, known as Association Day. The commodity associations usually commemorate the founding of the market annually on the day of celebrations, members of the

\footnotetext{
${ }^{23}$ Ogunbunmi, O.A. "Rural-urban market in Oyo 1900-2000" M.A. Dissertation, Institute of African Studies, Ibadan, University of Ibadan, 2005

${ }^{24}$ Ibid

${ }^{25}$ Public Administration and the Conduct of Community Affairs among the Yoruba in Nigeria. S. Bamidele Ayo, Ph.D.
} 
associations are attired in colourful uniforms (Aso egbe) with radiance of joy and hopes of development in the entire market. ${ }^{26}$

\section{Features of Market Association}

Most of the associations already identified, had membership that cut across both local and regional boundaries. The more widespread the membership of any particular association was, the greater the influence it exercised on politics and economy in the society.

Apart from this, a clear cut leadership structure was an important feature of association in Yorubaland. In fact, for Ibadan and other parts of the Yoruba country during the $19^{\text {th }}$ century, each association in the town whether with membership spread that was local or inter-kingdom, often had a leadership structure in its organisation. ${ }^{27}$ Most of the associations in Yorubaland are organised on the basis of what they produced or manufactured, the services they provided or their articles of trade such as egbe alata-association of pepper sellers; egbe eleja-association of fish dealers; egbe elepo- association of red oil dealers; egbe eleran isoassociation of sheep or goat or cattle dealers. The importance of these associations to the economy of the respective Yoruba towns in the pre-colonial period was that each of them assisted the state to make their valuable articles or services readily available at competitive rates for prospective customers; engaged in the maintenance of peace and order in the various markets at no cost to the state, and provided a set of rules or procedure of the profession, to which members were compelled to conform with to enhance the economic prosperity of the state. $^{28}$

\section{Market Associations and the Socio-Economic Development of to Oja'ba}

Market associations are important phenomenon in the organization and development of market in Yoruba society. Oral tradition had it that they were adopted by the traditional market administration before the emergence of colonial rule in Nigeria. The exact date of the origin of market association in Yoruba society is uncertain and has not been ascertained by economic historians of Africa. However, it is generally believed that production and

\footnotetext{
${ }^{26}$ Interview with Alhaji Nureni Adebayo Akanbi, family head of Oluyole Compound Oja'ba Ibadan, $25^{\text {th }}$ of April, 2020

${ }^{27}$ T. Falola, Political Economy of a Pre-Colonial African State: Ibadan, 1930-1900. Ile-Ife: Unife Press Ltd, 1983, p.169

${ }^{28}$ Vagale, L.R. (1972). Anatomy of Traditional Markets in Nigeria. Ibadan University: Institute of African Studies.
} 
marketing of goods began to be organized through market association. Each of these associations had a recognized head. At Oja'ba market, traders were organized into a number of associations whose executives oversee the day to day administration of the associations. ${ }^{29}$

Field investigation revealed that at Oja'ba market, there are over thirty seven trade associations found within the market. These associations include egbe alarabo (Association of animate objects) egbe alajapa (Associations of inanimate objects), egbe alaso (Associations of cloth sellers), egbe elelubo (Association of Yam flower sellers), egbe oloronbo (Association of orange sellers), egbe eleran (Association of butchers) egbe elero (Association of millers) egbe alata (Association of pepper sellers) egbe olowo (Association of broom sellers) etc.

The responsibility of members of these market associations in the market, is to see to the welfare and economic interest of their members. Besides, these associations ensure that law and order are strictly adhered to by members and they are saddled with the responsibility and safety of their members' goods in the market. In case of theft, it is promptly reported to the president of the association and proper arrangement will be made to investigate, arrest and punish the culprit.

According to Hill ${ }^{30}$, market association is an association of sellers, in a particular market, which handles a particular commodity and serves the interest of its members. Right from the evolution of markets, market association was set up into guilds i.e. association that control the production and sale of different commodities in the market. According to Fadipe, members of each association are usually compartmentalized on the basis of the line of goods they sell or specialize in. ${ }^{31}$ Akinjogbin and Osoba ${ }^{32}$ contended that market association is an important development in the marketing system. The Yoruba traders who embarked on long distance trade organized themselves into trade guilds. He gives them a general name under the umbrella of egbe, egbe alajapa and egbe alarobo. The alajapa guild trade largely in inanimate objects such as medicinal herbs, food items etc. while the alarobo guild traded in

\footnotetext{
${ }^{29}$ Ibid

${ }^{30}$ Hill, P. "Notes on Traditional Market Authority and Market Periodicity in West Africa". Journal of Africn History, Vol, VII2, 1996, p.295.

${ }^{31}$ Fadipe, N.A. The Sociology of the Yoruba. Ibadan: University of Ibadan Press, 1970,

32 Akinjogbin, I.A. and Osoba, S.O. Topics on Nigerian Economic and Social History, Nigeria: University of Ife Press Ltd.
} 
animate objects such as fowls, goats and so on. Members of these guilds engaged in both local and long distance trade.

The contribution of these market associations to the growth and development of Oja'ba market as well as Ibadan cannot be over emphasized. In addition, members of these associations usually pay subscription on each meeting day. This amount varies from one association to the other. The purpose of this monthly or weekly contribution is to assist members of the associations in time of need. Essentially, the associations through its revenue generated by members, use the money to provide short term credit facilities to its members, maintain good health hygiene practices and pay for services provided by government warehouse to store their goods. ${ }^{33}$

The idea of these contributions is to help the members of the association to raise capital. The most organized way of sourcing capital to start a trade was the system of ajo (daily contribution). ${ }^{34}$ This system loomed large in marketing operation in Oja'ba market. ${ }^{35}$ The system of ajo was regarded as esusu system. A system which a group of individuals, make fixed contribution of money at fixed intervals, the total amount contributed by the entire group is assigned to each of the member on rotational basis. ${ }^{36}$ If a member does not have enough capital to transact, the association can provide short-term loan for its members on no or low interest rate. All the associations in the market jointly contribute money to send people to neighbouring towns to purchase goods at subsidized price to their prospective members.

Furthermore, field investigation reveals that these associations helped to promote mutual understanding among members of the same association by providing necessary and timely information to help and facilitate their trading network. This is particularly true in the sense that members of these associations usually assist one another to discover new area of available goods, no where to buy their socks at cheaper rates from the producers.

More importantly, the associations' main goal is to guarantee the economic interest of their members; they prohibit non-members of their associations from selling their goods at

\footnotetext{
${ }^{33}$ Oral interview with Mrs Mary Majobaje, age 62, Trader, Ibadan, $28^{\text {th }}$ August, 2020

${ }^{34}$ Olaoba, O.B. Urban and Rural Marketing: Bodija Market in Ibadan, 1987-1995, Ibadan: John Archers Ltd.

${ }^{35}$ T. Falola, Politics and Economy in Ibadan, Ibadan: Modesto Publishers, 1989, p.23

${ }^{36}$ Bascon, W.A. "The Esusu: A Credit Institution of Yoruba", Journal of the Royal Anthropological Institute, Vol.82, 1952, p.34.
} 
Oja'ba market. This greatly discourages the trading activities of non-members, who spoil the market for genuine members of the association.

Also, these associations are formed to act as pressure group to influence the price of the producers in the villages where they buy their stocks. In fact, this partly explains one of the reasons for the formation of such association, that is, to checkmate the unnecessary increase in price of commodity by producers. Hence, the associations have contributed significantly to checkmate the arbitrary increment in the prices of goods from the producers by not buying from them.

Field investigation also revealed that these associations assist their members to avoid unnecessary increase in the cost of transportation of their goods bought from producers to the market. This is so in order to reduce the cost of goods for the final sale to the consumers in order to maximize profit. Oral interview with Mr. Akanji, a popular commercial driver, in the town, revealed that the traders determine the price of transport cost, and if a driver refuses to accede to the customer's wish, the trader would look for better alternative. ${ }^{37}$

More importantly, it is worthy to note that these associations also contribute money to clear public heaps of refuse which accumulate around the centre of the market. Although this is supposed to be undertaken by the local government authority and since the beginning of 1977, this proved to be unreliable and consequently the associations continue to clear the refuse, when the council fails to fulfill its obligation.

Market associations also play significant role during socio-cultural activity in the town. They usually participate during important ceremonies in the town.

In the recent time, these associations participate actively in political rallies and conventions toward the political development of the state and Nigeria as a whole. It would be recalled that during general elections in the country, market associations are always in the forefront. The activities of market associations in Oja'ba market had contributed greatly to the socio-economic life of the people. They assist one another in times of naming ceremony, birthday celebration, wedding and funeral or burial ceremony of their members.

Furthermore, market associations are responsible for the general order and care of the market. They are also responsible for the erection, repair and allocation of stalls to traders in

\footnotetext{
${ }^{37}$ Oral interview with Mr. Akanji Sunday, age 55, Driver, 20 ${ }^{\text {th }}$ August, 2020
} 
the market (Oladiti, 2000:16). ${ }^{38}$ These associations have a great deal of moral authority over their members. Such authority is used in performing judicial functions especially in quarrels arising from trade, debt and simple cases of fraud. They also occupy important places in political system. It would be called that these associations began basically with the aim of protecting and organizing the trade. Hence, each association evolved a more or less detailed organization with olori-egbe President and igbakeji-olori-egbe (Vice-President). Each association comes to perform definite function in the town and always put on their membership uniform.

Apart from the aforementioned contributions, the associations have also contributed to the growth and development of Oja'ba market as an entity. Although Oja'ba market is under the control of local government authority, they embark on some developmental projects to benefit and promote market transaction and other activities. To achieve this, the presents of market associations are summoned by the babaloja who is in charge of the market. In case of any project, it will be discussed and the estimated cost of the project will be shred accordingly among the various associations, which will be contributed by members. For instance, in 1983, 1986 and 1990 respectively, members of each association in the market contributed money to clear market environments.

More importantly, market associations in Oja'ba market have contributed greatly to the increase in trading activities which in turn led to the growth of the market. The level of security provided in the market by the market associations promoted peace in the market.

Furthermore, market association in Oja'ba market have promoted a conducive atmosphere for mutual understanding among themselves. In addition to this, on every market day, sellers who have ample stocks and will collect the money at the end of the market. Thus, a palm oil seller can give another seller some kegs of palm oil value at five thousand naira and it might later be sold for five thousand five hundred naira. In this situation five thousand naira is given to the one who gives the item while the profit of five hundred naira belongs to the person who sells the item.

Market association has contributed in no small measure to the overall development of the market. information gathered through the field work revealed that, some of the locked up

\footnotetext{
38 Oladiti, A.A. “Traditional Market in Modern Ibadan: A Case Study of Oja'ba 1970-1996”, B.A. Dissertation Department of History, University of Ibadan, 2000, p.16
} 
shops built in the market were pioneered by market association. Interview with the chairman of pineapple sellers' association revealed that, at every meeting of the association, certain amount is contributed for the development of the association, and part of the money is used to build shop around the market.

The periodic market at Oja'ba is primarily meant for the display of locally farm produce such as yam, cassava, garri, beans, fruits, vegetables, pepper and other food stuffs. The difference in vegetation zone of Nigeria, force people from one zone to depend on the other zones for what they cannot produce in abundance. With the rise of urbanization, modern agricultural technology and more efficient transportation infrastructure, Ibadan people no longer depend on its own agricultural produce alone. For instance, oral interview with Mrs. Kafaya, a beans seller in the market, revealed that a great portion of the white bean, pepper and tomatoes come from north and are redistributed in Ibadan through Oja'ba market. Yams come from Kisi, Ilorin, Iyagba and Ekiti towns. These items were brought to the market through the market Associations. The products brought to Ibadan are not only sold in Oja'ba market, but also in many markets in the city dealing with the sales of farm produce, food stuff, traditional cloths like ofi/aso oke and the likes.

\section{Problems confronting Oja'ba market in Ibadan}

Managing traditional market is a great challenge in any part of the world especially African countries. Though Oja'ba helps its customers meet their daily needs, it has got various problems that challenges the traders and its environs. Adulteration of commodities sold is a major problem faced by patronizers. This means they pay much money for substandard products. The buyers that fall in this trap are those that are not familiar with the market. The traders adulterate products like palm oil, vegetable and groundnut oil, kerosene and the likes. They do this to increase their profit.

Most of the traders are illiterates and this show in their dressing, appeal to customers and their general interactions with their customers. Also, the stalls of these illiterate traders are always dirty compared to those of educated traders. Due to illiteracy, most traders lack

the ability to convince buyers on market operations. For example, an enlightenment trader would rather give an explicit explanation about the factors determining the selling price of commodities than abuse the buyers as their illiterate counterparts would do. 
This leads us to another major problem in Oja'ba and this is the problem of child abuse. This involves the engagement of under-aged children in trade. Such children as should be in school are found hawking goods and wares for parents and guardians thereby exposing such children to a lot of dangers e.g. accident as the children are expected to cross major roads while hawking their wares. Also such young children are easy prays to hoodlums, who might lure such children into some vices like smoking and drinking. Cases have even been heard of young girls who have been raped.

Another major problem that serves as deterrent to normal trading activities in the market is poor sanitation. Although the Ibadan South East Local Government made provision for public incinerators in the market, the traders, do not make proper use of these incinerators, ${ }^{39}$ instead, they litter the whole market, drainage passages and canals with dirt which poses a major threat to health of traders and buyers alike and also the residents of the area. There are health workers from the Ibadan South East Local Government who should carry out the function of sanitary inspectors by enforcing discipline in order to maintain cleanliness in the market. Rather than do their job by making unco-operative traders pay the necessary fines and make sure they stop being indiscipline, they (health workers) just collect money from the traders without any record. This is just a clear cut case of extortion by the health workers and at the end of the day, no job is done.

Considering extortion on a wider and larger scale, it is a major problem that the traders in Oja'ba still encounter. It is not only the health workers that extort traders in the market but even the Police and members of the Local Government Taskforce. ${ }^{40}$ This is as testified by a food stuff seller in Oja'ba, Mrs. Oredun on the $25^{\text {th }}$ of April 2010 and Mrs Majeobaje ${ }^{41}$ who sells vegetable oil in the market.

The lack of mechanism for food quarantine is the major challenge that is facing the market. About seven years ago, the Electronic media came out with stories of people in the city dying shortly after a meal. This was traced to the fact that foodstuff are brought to and sold without formal inspection to certify them consumable.

\footnotetext{
${ }^{39}$ Great Strides at Mapo Hill, the seat of Ibadan South East Local Government by Gbenga Abiola, first published 2005.

${ }^{40}$ Interview with Mrs. Oredun, trader at Oja'ba, on the $25^{\text {th }}$ of April, 2010.

${ }^{41}$ Interview with Mrs. Majobaje, Trader at Oja'ba on the $26^{\text {th }}$ April, 2010.
} 
The next is a problem for both farmers and traders, it is the lack of modern storage facilities which leads to the destruction of commodities by rodents and other pests and excessive heat which makes them lose value. This makes the hoarding of commodities very risky for traders who intend to sell their products at a higher price and at a later time.

Other major challenges facing the administration of Oja'ba are as follows:

Basic Market Infrastructure - The prevalence of socio-economic problems in Oja'ba market are resulted from the lacing or inadequate fundamental infrastructure that an ideal market should have for the convenience of the people patronizing them. This basic infrastructure includes: public toilets, portable water supply, security of goods, waste containers and many others.

Environmental Pollution - The physical environment of this market is polluted with solid waste as a result of the waste container that is not adequate in the market. It is obvious that one waste container that is on ground in each of the market cannot coop with the waste being generated in these markets daily. Also, general habit of people by dumping solid waste to the available open drains and stream has contributed majorly to the pollution of the markets physical environment.

Traffic and Transportation Flow - On-street trading and on-street parking of vehicles that characterized the market have seriously affected the flow of traffic with the ceaseless traffic hold up and traffic jam that is mostly experienced around this market area. The access roads within the market have been taken over by traders and buyers for trading and transaction activities. This makes it difficult for vehicles to have access to the roads for loading and offloading of goods. Also, there is no provision for organized parking space in either of the markets to take care of parking of vehicles of the traders, buyers and other vehicle owners who has one thing or the other to do in the markets. This deficiency encouraged the parking of vehicles along the road network within the markets which causes obstruction of traffic movement for both vehicular and pedestal.

Loading and Off-loading Bay - An organized market should have loading and offloading bay to enhance free flow of vehicles and convenient loading and off-loading of goods for traders and buyers. But the recognizance survey to the market reveals that there is no facility for loading and off-loading bay. This is one of the factors responsible for the traffic problems within the market because any vehicle that want to load or off-load goods has to park on the 
highway while other vehicles would have to wait till the activity is done before there can be free flow of traffic again. At the same time, commercial buses, tricycle and okada, parked by the road side to pick and also alight passengers, right from Beere roundabout to the other end of the market, which always cause a lot of hold-up on the busy road.

Coverage for Display of Goods - Oja'ba market is located within the core residential area of Ibadan, this makes space allocation very difficult and encourage the traders to display their goods on the highway and access roads within the markets.

Waste Disposal and Management - There is no any legal responsibility to be enforced in the market that would see to the general sanitation of the market to enhance clean, viable and healthy physical environment. This deficiency has also contributed greatly to the pollution of the physical environment of the markets.

Public and Private Sector - There have not been any private sector intervention to address the challenges in the market. The public sector interventions identified are either inadequate or not functioning again. Neglect of this market by both public and private sectors has contributed to the inherent challenges identified in the markets.

People's Attitude - The attitude of people to change in the pursuit of effective and efficient management of this market is a major concern. People do not want a change and there cannot be progress in addressing the challenges of this market without a change. This fact was established by the researcher when the traders were not cooperating in giving necessary information thinking that the research exercise would affect their socio-economic welfare in terms of displacing them from displaying their goods on the access roads and relocating the market to somewhere else.

These problems have been from the inception of the market. Moreover, for Oja'ba to achieve its aim of provision of daily needs, the government should take necessary steps possible to correct these societal ills in Oja'ba. Not to forget, the disputes among traders ${ }^{42}$ that are at times resolved by the family head of Oluyole compound, in Oja'ba. These disputes also cause a major problem in Oja'ba.

\section{Conclusion}

\footnotetext{
${ }^{42}$ Interview with Alhaji Nureni Adebayo Akanbi, Family Head of Oluyole Compound Oja’ba,Ibadan.
} 
It has been established in this study that the growth and development of Oja'ba market in Ibadan is largely due to the activities of the various traders' associations, dealing in different kinds of farm products and other items both within and outside the town. Indeed, women formed the major dominant groups which normally traded at the market. However, since the inception of Oja'ba market both male and female took active part in the production, transportation and marketing of market commodities. The functionality of market in colonial and contemporary period has been uncovered in this study.

The study also highlighted some of the challenges in marketing activities at Oja'ba and what has been done to overcome them. The roles of various market associations were examined in the study. These associations had contributed in no small measure to the development of the market. They have also contributed to the development of market by acting as intermediary between alarobo (middlemen) and oloko (producers). This was done in order to avoid unnecessary rise in the prices of commodities. In addition, these associations come together to safeguard the economic interest of their members. They also acted as price regulators, engaged in the settlement of disputes and advised their members for better opportunities such as identifying new area for the purchase of market stock. Both the local government authority and market executives exercised control over the market by ensuring security, public safety, cleanliness and good hygiene within the market premise. Oja'ba market has been adjudged a traditional rural market in Yoruba society that has continued to play a vital role in the economic and socio-cultural life of the people in Ibadan. The trends in the economic achievements and commercial importance persist as vital component of wholesale and retail trade of food items in the market. The increasing tempo of urbanization, improved transport system and road network have contributed significantly and positively in the social condition of the market. Above all, the great success at Oja'ba market today is as a result of immense contributions of various market associations and the stake-holders in the market. In a nutshell, this work has shown that Oja'ba market has played and it is still playing crucial roles in the traditional economy and commercial activity of the town. Thus, the market has been the nucleus of economic achievement and prosperity of traders in the community. Thus, Oja'ba market continues to survive because of the ever increasing demand for food supplies and the central position of the market. 


\section{References}

Akinjogbin, I.A. and Osoba, S.O. Topics on Nigerian Economic and Social History, Nigeria: University of Ife Press Ltd.

Akintoye, S.A. (1977), Revolution and Power Politics in Yorubaland 1840-1893. Ibadan Expansion and the Rise of Ekitiparapo. London: Longman, 1977, p.15

Bascon, W.A. "The Esusu: A Credit Institution of Yoruba", Journal of the Royal Anthropological Institute, Vol.82, 1952, p.34.

Fadipe, N.A. The Sociology of the Yoruba. Ibadan: University of Ibadan Press, 1970,

Gbenga Abiola, Great Strides at Mapo Hill, the Seat of Ibadan South East Local Government, 2005.

Gbenga Abiola, Great Strides at Mapo Hill, the Seat of Ibadan South East Local Government, 2005.

Great Strides at Mapo Hill, the seat of Ibadan South East Local Government by Gbenga Abiola, first published 2005.

Hill, P. "Notes on Traditional Market Authority and Market Periodicity in West Africa". Journal of Africn History, Vol, VII2, 1996, p.295.

Ogunbunmi, O.A. "Rural-urban market in Oyo 1900-2000" M.A. Dissertation, Institute of African Studies, Ibadan, University of Ibadan, 2005

Ogunsanwo, A.T. "Traditional market in Modern Ibadan: A Case study of Oje market, 19601984”, B.A. Dissertation, Department of History, University of Ibadan, (1985), p.18

Oladiti, A.A. "Traditional Market in Modern Ibadan: A Case Study of Oja'ba 1970-1996", B.A. Dissertation Department of History, University of Ibadan.

Olaoba, O.B. Urban and Rural Marketing: Bodija Market in Ibadan, 1987-1995, Ibadan: John Archers Ltd.

Oral Interview with Alhaji Nureni Adebayo Akanbi, family head of Oluyole compound, Oja'ba

Oral interview with Mr. Akanji Sunday, age 55, Driver, $20^{\text {th }}$ August, 2020

Oral interview with Mrs Mary Majobaje, age 62, Trader, Ibadan, 28 ${ }^{\text {th }}$ August, 2020

Oral interview with Mrs. T. Oredun, age 50, Foodstuff trader, Oja'ba Ibadan, $28^{\text {th }}$ August, 2020

Public Administration and the Conduct of Community Affairs among the Yoruba in Nigeria. S. Bamidele Ayo, Ph.D. 